\title{
AN ANALYSIS OF PRE AND POST-ACQUISITION FINANCIAL PERFORMANCE OF TARGET CZECH BANKS: A COM PARATIVE ANALYSIS
}

\author{
Long Hoang Pham \\ The University of Economies, Prague, Czech Republic
}

\begin{abstract}
The objective of the study is to analyze and compare the pre and post-acquisitions financial performance of four banks, namely ČSOB, Komerční banka, Česká spořitelna and Hypoteční banka through ratio analysis, with greater emphasis on ROA, RONW, EPS, DE and NPM as financial efficiency parameters. Data were collected from the published annual report and accounts of the selected banks and were subsequently analyzed applying Wilcoxon signed rank test through statistical package for social sciences (SPSS). The data was being collected for three years before and after the acquisition. The study concluded that $M \& A$ of the selected firms have resulted in no significant change in the financial performance of these firms. Our study recommended that banks should be aiming more for profit for enhanced financial performance to reap the benefit of $M \& A$ in the Czech banking sector.
\end{abstract}

Keywords: acquisitions, bank performance, profitability, Wilcoxon signed ranks test.

DOI: http://dx.doi.org/10.15549/jeecar.v1i2.60

\section{INTRODUCTION}

In today's globalized world, mergers and acquisitions (M\&As) are being increasingly globally used for improving competitiveness of companies through gaining greater market shares, reduce business risks, entering new markets searching for economies of scale, synergies and many other reasons. Mergers and acquisitions (M\&As) become the major force in the changing environment. One of the primary objectives for $M \& A$ is to attain growth at the strategic level in terms of size and customer base and $M \& A$ in the banking sector has become familiar a common phenomenon across the world. Banks play a very important role in driving up the entire economy of any nations. With the power of M\&A in the banking sector, the banks can achieve strategic benefits, significant growth in operations and minimize their expenses to considerable extent. Therefore, more and more international and domestic banks all over the world are engaged in $M \& A$ activities. In recent years, numerous researches in economics and corporate finance have measured the profitability of companies and banks by financial factors before and after $M \& A$, since investment decisions are directly related to the financial factors. The value of this approach is that it can be used to diagnose strengths and weaknesses of the company's performance, whether it is profitable or not. Whether $M \& A$ lead to improved performance is a debatable issue. No definite conclusion can be drawn thus there is a need to explore this area further.

In this paper, we will examine the postacquisition performance of the Czech banks involved in $M \& A$ activities by using accounting approach (ratios). The present work is motivated by the very shortage (none) of empirical evidence on the impact of $M \& A$ for performance in Czech banks. The current stream of literature dealing with the effects of $M \& A s$ on Czech banks consists of small regional analyses - among other Eastern European countries (Bonin et al., 2005; Clarke et al., 2005) or cross-border analyses (Correa, 2008; Beccalli et al., 2008). Nevertheless, the above mentioned studies do not explicitly focus on the impact of M\&As on the accounting profitability of the Czech banking institutions. This paper therefore aims to fill in this gap. To our knowledge, this is the first study to deal with post-acquisition profitability of target banks in Czech. Specifically, it focuses on acquisition deals that took place in the period of 2000-2010, involving 4 Czech banks. We measures performance by using an indicator capturing bank profitability: 
return on assets (ROA), return of net worth (RONW), net profit margin (NPM), Debt-equity (DE) and earnings per share (EPS).

The main objective of this paper is to analyze whether the acquired Czech banks have achieved financial performance efficiency during the post-acquisitions period specifically in the areas of profitability and solvency standards. Moreover, to analyze the effect of these mergers and acquisitions announcements on the stock prices of the selected banks. Wilcoxon signed rank test through statistical package for social sciences has been performed to determine the significance differences in financial performance three years before and three years after the acquisition activities.

The scope of the study is confined to mergers and acquisitions undertaken in the Czech Republic, focusing on 4 acquisitions - 4 target banks, from the year 2000 to 2010. The study is based on the facts and figures available for the selected banks through sources like their Annual Reports or Obchodni rejstrik a Sbirka listin.

\section{HYPOTHESIS}

We have set the following hypothesis for the study which we will test:

Ho: There is no significant difference between the financial performance of the banks before and after the acquisition that is Ho: $\mu=0$.

$\mathrm{H1}$ : There is a significant difference between the financial performance of the banks before and after the acquisition that is $\mathrm{H} 1: \mu \neq 0$.

\section{CZECH BANKING SYSTEM}

After the regime changed in 1989, Czech authorities have come up with economic reforms to reform and enhance the national economy and to develop a healthy banking system. This process involved a major reorganization of the bank industry such as the transition of closed system of one-tier to a twotier open banking system. Based on the Act No. 21/1992 Coll., for banks and savings banks, a new legislative enables to establish new commercial banks. Moreover, it was allowed for foreign banks to enter into domestic market in form of subsidiaries. During the year of 1990, the four new universal commercial banks were established. The banking sector was rapidly developing until late 1993 (57 banks). Since 1994, due to bad loans, opaque activities on the capital market and inexperience of banking managements, the bank sector faced with liquidity and solvency problems (Bartosek et al., 1998). The result was a significant amount of non-performing loans and with risky practices and mismanagement it has affected the financial restructuring and privatization of the banking sector. Therefore, a stronger supervision and the establishment of a better regulatory framework to ensure financial stability were needed. The Czech National Bank (CNB) assumed this important role and with efforts of enhancing and strengthening the regulatory system. The decision to integrate financial market supervision was of critical significance. Under a government resolution made at the end of August 2005 and following amendments to the relevant legislation, supervision of the entire financial market was integrated and concentrated into the Czech National Bank as from 1 April 2006. (Tůma, 2006). In 1997, CNB came up with a stabilization program, which should help to eliminate low-quality assets in small and medium-sized banks. The pace of banks' restructuring and privatization increased, foreign banks entered the market, thus increasing the competition, the condition of the national economy improved (Vencovsky, 1999). All these changes resulted in a larger volume of banking activity and a better financial stability of the sector. The year of 2004 was an important milestone and turning point for the Czech economy and for the Czech banking sector as well, namely the admission to the European Union in January 2004. It triggered significant structural changes, increase of competition among banks and harmonization of legislation relating to bank with European Community law. Initially, thanks to the regulation, Czech banks and partly financial institutions performed well during the world crisis beginning in 2007. This was explained by the small portion of financial securities held, the lack of toxic assets, the low share of nonperforming loans, excess of liquidity, good capitalization and high profitability of the banks (Singer, 2009). However, the general factors that led to the global economic crisis also caused banking business to slow down (the loan market witnessed a significant stagnation). Although all were at a manageable level and there are no concerns for financial stability. So far there was no need for banks' capitalization with public funds. Moreover, national authorities claim currently, that Czech banking system may be deemed as stable, with capitalization, solvency and liquidity levels at 
normal requirements (IHNED, 2011, Ceska bankovni asociace, 2013).

\section{LITERATURE REVIEWE}

Mergers and acquisitions are globally used for expanding business activities to improve performance, achieving business growth and competitiveness. The literature has identified several factors that explain acquisitions in the banking sector: economies of scale (personnel and informational improvements on borrowers' creditworthiness), IT centralization and cash management, obtain market power, geographical diversification bringing benefits in terms of risk reduction, grown to a size (implicit subsidies) that prevents them from gaining benefits from the a too-big-to-fail status (Panetta et. Al., 2009, Demirguc-Kunt et. al., 2010).

The increasing attention recognized to bank $M \& A s$ over the last decade has given rise to empirical studies available on the subject. According to Altunbas and Ibanez (2008) most of the studies measuring the level of success of bank $M \& A$ in terms of financial performance follow two different research methods used in evaluating the success of these transactions.

One is the operational performance approach including studies between $M \& A s$ and the efficiency of the banks involved, either measured performance with financial/accounting approach based on accounting variables (Mylonidis et. al. 2005; Badreldin et. al. 2009; Correa 2008) and studies investigating the cost and profit X-efficiency (Ekkayokkaya et. al., 2009). The other approach comprises studies investigating the effects on bank M\&As takes a more comprehensive approach and uses event study methodology (market reaction changes in share prices) (Knapp et al., 2005; DeLong and DeYoung, 2007). Since our research paper use operational performance approach, we will focus on findings of some of these studies. Overall, the dynamic analyses on M\&As provide mixed inconsistent results. The existent empirical studies can be analyzed and characterized into three different groups: (i) a significant deterioration (ii) a significant improvement in the post-M\&As performance, and (iii) no improvement, performance remain unchanged.

In the first category, the numerous of studies conclude that $M \& A$ activities in the banking industry have not had a positive influence on performance or are seldom realized. In the work of DeLong et al., (2007), there is no clear evidence of positive effects of $M \& A$ on profitability ratios such as ROE and ROA for US banks. M\&A have often failed to add significantly to the performance of the banking sector. Further, some other studies comparing pre and post $M \& A$ performance found the potential efficiency gain from merger and acquisitions are rarely materialized (Beitel et. al., 2004; Amel, et al., 2004). Schiereck Dirk et. al., (2009) explained the relationship between bank reputation after $M \& A$ and its effect on shareholder's wealth. This study considered 285 European $M \& A$ transactions announced from 1997 to 2002 and finds that on average wealth was not significantly affected by $M \& A$. Kemal (2011) used accounting ratios to analyze the financial performance of Royal Bank of Scotland (RBS) after merger. Study analyzed financial statements for four years (2006-2009) by using 20 ratios. Results shown that merger fails to improve the financial performance of the bank.

However, some of scholars have contrary views. Rhoades (1993) tested the impact of $M \& A$ in banking industry on efficiency and profitability for the domestic and cross border mergers. The result shows that mostly the domestic $M \& A$ improve the cost efficiency and little improvement of profit efficiency and little or no improvement in the profit or cost efficiency in the cross border mergers. In the work of Focarelli et al. (2002), they found that after M\&A, Italian banks improved ROE, because of decrease in capital and improving lending policies by restructuring the loan portfolio of the acquired bank, which resulted in higher profits. Campa et. al., (2006) concluded that $M \& A$ resulted in significant improvement in the target banks' performance, return on equity increased by an average of $7 \%$ two years after transaction. Cornett et al (2006) examined the operating performance around commercial bank mergers and found that industry adjusted operating performance of merged banks increases significantly after the merger. Large bank merger produce greater performance gains than small bank mergers. Altunbas et al., (2008), examining the impact of strategic similarities between bidders and targets on post $M \& A$ financial performance in EU, conclude that bank mergers resulted in improved return on equity, particularly in the case of cross border mergers. Fraser et al. (2009) provides evidence on operating performance changes (pre and post M\&A) for U.S. banks acquired by non-U.S. banking organization with sample of 83 commercial banks. Badreldin et.al. (2009) 
investigate Egyptian banks which have undergone M\&A during 2002-2007. Their analysis suggested an increase in the performance when companies are compared with the pre-merger performance. The study concluded that $M \& A$ in the Egyptian banking sector showed a significant profitability improvement and a small positive impact on the credit risk position. Sufian et. al. (2010) observes Malysian banking sector on the basis of their technical efficiency after M\&A. They found found a higher mean technical efficiency level when they compare it with the premerger period. Sinha Pankaj et al., (2011) studied a pre and post analysis of firms and concluded that it had positive effect as their profitability, like Earnings before Interest and Tax (EBIT), Return on shareholder funds, Profit margin, Interest Coverage, Current Ratio and Cost Efficiency and in most of the cases deteriorated liquidity.

Contrary to researches mentioned above, a numerous of studies found no evidence of any performance improvement after the $M \& A s$. Vennet (2002) found partial profit efficiency enhancement, but not with any tangible gains in terms of cost efficiency and return on assets for European target banks on the first year after an acquisition. Correa (2008) concluded there was no positive performance effect in the first two years after cross-border acquisitions. He explained that profitability was affected by a decrease in the banks' net interest margin and by the lack of cost-efficiency gains. In the work of DeLong et. al., (2007) there is no evidence of clear positive effects of $M \& A$ on profitability ratios such as ROE and ROA for US banks.

Overall these studies provide mixed evidence with unclear relationship between $M \& A$ and performance. According to Beccalli et. al., (2008), there are several explanations for this puzzling evidence: absence of bestpractices guidelines for planning and executing increasingly large and complex acquisitions, failure in considering the mean-reversion behavior in industry-adjusted performance; longer time (up to five years) needed to realize efficiency gains, difficulties of integrating broadly dissimilar institutions; increased costs associated with changes in post-merger risk profiles and business strategies.

In short, there are none of studies giving evidence from measure the profitability performance target banks located in the Czech Republic involved in M\&A deals. This study therefore aims to extend and incorporate the existing literature.

\section{DATA AND METHODOLOGY}

This study is a descriptive research, which are fact finding and describing the characteristics of a particular individual or a group. This research aims at studying the pre and post-acquisition impact of four selected $M \& A$ deals for transferor banks from the year 2000 to 2010 where the hypothesis would be tested using data three years before and after the acquisitions. The research is based on secondary data, because of the requirements of the research objectives. The data set is obtained by combining three sources: Zephyr database provided by Bureau van Dijk for data on the $M \& A$ transactions; bank websites for balance sheet and profit and loss data (annual reports) of some of the banks involved in $M \& A$ operations and financial statements provided by Obchodni rejstrik a Sbirka listin, where data on bank websites were not available.

The sample is limited to acquired (target) banks located in the Czech Republic. The list of $M \& A$ transactions was taken from Zephyr database, was calculate with only completed transactions, excluded the deals in which the target bank's control was not transferred to the acquirer The sample comprised 11 transactions, out of which five were mergers and six were acquisitions. Since we focus on post-acquisition performance, we took into consideration only completed acquisitions and where data (balance sheet, financial statements) were available for 3 years pre and post-acquisition transactions. The final sample includes four transactions. Although the size of the sample is relatively small compared to other studies conducted in the Europe or USA, we must emphasize that the total number of $M \& A$ in the Czech banking sector is very small comparing with other countries, with a total number of banks at time of publication of 44 banks (CNB 2014). In addition, we considered the final sample can be satisfactory as it includes all the acquisition operations involving Czech target banks in the aforementioned period and also reliable in comparison to prior accounting studies that were conducted in significantly larger markets. 
As far as the accounts used were concerned, we used the consolidated one. We also used the financial statements prepared in accordance with IAS/IFRS. The pre and post-acquisition analysis is done using the ratio analysis technique where all the key ratios of the acquired banks are compared like the Profitability ratios, Liquidity ratios etc. are compared 3 years before and after the deal. Wilcoxon Signed Rank test (using SPSS) are carried out to assess the difference in the pre and post- acquisition performance of the selected banks.

Wilcoxon Signed Rank Test is a nonparametric statistical hypothesis test for the case of two related samples on a single sample and is used as an alternative the paired student's t-Test. The Wilcoxon signed rank test compares the median of a single column of numbers against a hypothetical median. It is used when the sample cannot be assumed to be normally distributed in case of two related sample or repeated measurement on a single sample. Here it is used to find the significance of the pre and post-acquisition increase or decrease.

The Wilcoxon signed ranked statistic defined as: where
I(.) is an indicator function, =median;

The raw data were obtained for the above mentioned parameters (see appendix) and signed rank test is carried out to assess the difference in the performance between pre and post-acquisition. In our study represents pre-acquisitions and represents postacquisitions. The test statistic $z$ is computed and probabilities observed are compared with desired level of significance (0.05) to accept or reject null hypothesis.

The advantage of Wilcoxon Signed Rank Test comparing to other non-parametric test is that it takes into account both the sign and magnitude of the abnormal performance. In this study the magnitude of difference is defined as greater than 0 (for a post-acquisition performance increase) and less than 0 (for a post-acquisition performance decrease).

The sample consists of 4 major acquisitions made by foreign banks and targeted Czech banks from the year 2000 to 2010 (see table 1)

Graph 1: A framework for determining the post- acquisition Performance of Banks in the Czech Republic

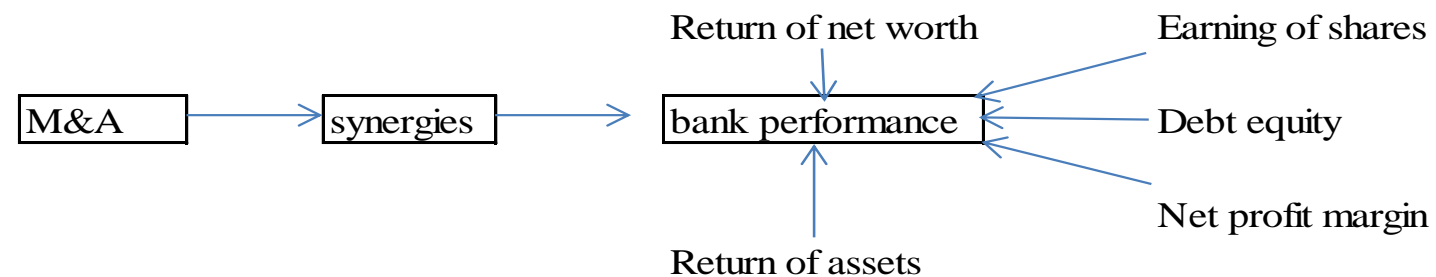

Source: Researcher's Conceptualization (2014)

Table 1: Descriptive of Transactions selected in the sample

\begin{tabular}{cllll}
\hline $\begin{array}{l}\text { Bank } \\
\text { s }\end{array}$ & $\begin{array}{l}\text { Transferor } \\
\text { Bank }\end{array}$ & $\begin{array}{l}\text { Transferee } \\
\text { Bank }\end{array}$ & $\begin{array}{l}\text { Resulting } \\
\text { entity }\end{array}$ & $\begin{array}{l}\text { Date } \\
\text { Transaction }\end{array}$ \\
\hline 1 & CSOB & KBC & CSOB & 2000 \\
& Komercni & Societe & $\begin{array}{l}\text { Komercni } \\
\text { banka }\end{array}$ & 2001 \\
2 & banka & Generale & Ceska & 2002 \\
3 & Ceska & Erste Bank & C
\end{tabular}




$\begin{array}{llll}\text { sporitelna } & & \text { sporitelna } \\ \text { Hypotecni } & \text { Hypotecni } & \\ \text { banka } & \text { CSOB } & \text { banka } & 2009\end{array}$

Source: database Zephyr, internet and newspapers.

Table 2: Definition of variables

\begin{tabular}{lll}
\hline Type & Ratio & Definitions \\
\hline \multirow{2}{*}{$\begin{array}{l}\text { Profitability } \\
\text { ratio }\end{array}$} & Net Profit Margin (NPM) & Net profit/total (net) revenues \\
& Return of net worth (RONW) & Net profit/average total equity \\
& Earnings per share (EPS) & Net profit/average total share \\
& Return on average assets (ROA) & Net profit/average total assets \\
\hline $\begin{array}{l}\text { Solvency } \\
\text { ratio }\end{array}$ & Debt Equity Ratio (DER) & Total liabilities/total equity \\
\hline
\end{tabular}

Source: Researcher's Conceptualization (2014)

\section{DATA ANALYSIS AND INTERPRETATION}

Table 3: Changes in Return of assets (ROA) Post-acquisition

The table depicts the changes in the ROA of the all the 3 years after the acquisition, ROA was selected banks after the acquisition. For eg. less as compared to the pre-acquisition years. Negative ranks- $3 a$ for ČSOB here shows that in

\begin{tabular}{|l|l|r|r|r|r|}
\hline & Ranks & ČSOB & Komerční banka & Česká spořitelna & Hypoteční banka \\
\hline \multirow{3}{*}{ ROA_post-ROA_pre } & Negative Ranks & $3 \mathrm{a}$ & $0 \mathrm{a}$ & $0 \mathrm{a}$ & $0 \mathrm{~b}$ \\
\cline { 2 - 6 } & Positive Ranks & $0 \mathrm{~b}$ & $3 \mathrm{~b}$ & $3 \mathrm{~b}$ & $3 \mathrm{~b}$ \\
\cline { 2 - 6 } & Ties & $0 \mathrm{c}$ & $0 \mathrm{c}$ & $0 \mathrm{c}$ & $0 \mathrm{c}$ \\
\cline { 2 - 6 } & Total & $-1.633 \mathrm{C}$ & $-1.604 \mathrm{~B}$ & $-1.604 \mathrm{~B}$ & $-1.604 \mathrm{~B}$ \\
\hline Z & & 0,102 & 0,109 & 0,109 & 0,109 \\
\hline Asymp. Sig. (2-tailed)* & & & & 3 & 3 \\
\hline
\end{tabular}

a. ROA_post $<$ ROA_pre

b. ROA_post > ROA_pre

c. ROA_post $=$ ROA_pre

*significance level was set at 0.05

\section{Interpretation}

By applying the Wilcoxon signed rank test, we can see that for all the four banks, the significance level is more than 0.05 (Table 3), therefore the null hypothesis is accepted that there is no significant difference between the pre and the post-acquisition performance on the basis of ROA of the banks.

But looking at the individual performance of the banks, then for Československá Obchodní
Banka (ČSOB) for all the 3 years, the ROA after the acquisition was comparatively less than pre-merger years. But for the rest three babks, there has been different for all 3 years after the acquisition, ROA was more than the preacquisition period. Overall, if we see the average pre and post-acquisition performance of the banks, the post-acquisition profitability performance on the basis of ROA, the postacquisition performance is better for 3 banks out of the 4 sample banks.

Table 4: Changes in Return of net worth (RONW) post-acquisition

The table depicts the changes in the RONW of the selected banks after the acquisition. For eg. Positive ranks- $3 b$ for ČSOB here shows that in all 3 years after the acquisition, RONW was 
more as compared to the pre-acquisition years.

\begin{tabular}{|l|l|r|r|r|r|}
\hline & Ranks & ČSOB & Komerční banka & Česká spořitelna & Hypoteční banka \\
\hline RONW_post-RONW_pre & Negative Ranks & $0 \mathrm{a}$ & $0 \mathrm{a}$ & $0 \mathrm{a}$ & $0 \mathrm{a}$ \\
\cline { 2 - 6 } & Positive Ranks & $3 \mathrm{~b}$ & $3 \mathrm{~b}$ & $3 \mathrm{~b}$ & $3 \mathrm{~b}$ \\
\cline { 2 - 6 } & Ties & $0 \mathrm{c}$ & $0 \mathrm{c}$ & $0 \mathrm{c}$ & $0 \mathrm{c}$ \\
\cline { 2 - 6 } & Total & 3 & 3 & 3 & 3 \\
\hline Z & & $-1604 \mathrm{~B}$ & $-1.604 \mathrm{~B}$ & $-1.604 \mathrm{~B}$ & $-1.604 \mathrm{~B}$ \\
\hline Asymp. Sig. (2-tailed)* & & 0,109 & 0,109 & 0,109 & 0,109 \\
\hline
\end{tabular}

a. RONW_post $<$ RONW_pre

b. RONW_post $>$ RONW_pre

c. RONW_post $=$ RONW_pre

*significance level was set at 0.05

\section{Interpretation}

From the analysis (Table 4), we can observe that for all, an acquisition performance of RONW ratio was better than the pre-acquisition period all years compared. So overall on the basis of the average pre and post-acquisition performance of the banks, the post-acquisition profitability performance on the basis of Return on Net worth, the post-acquisition performance was better for all four sample banks. However, the significance level is more than 0.05, therefore the null hypothesis is accepted that there is no significant difference between the pre and the post-acquisition performance on the basis of RONW of the banks.

Table 5: Changes in Net profit margin (NPM) Post-acquisition

The table depicts the changes in the NPM of the selected banks after the acquisition. For eg. Positive ranks- $3 \mathrm{~b}$ for ČSOB here shows that in all 3 years after the acquisition, NPM was more as compared to the pre-acquisition years.

\begin{tabular}{|l|l|r|r|r|r|}
\hline & Ranks & ČSOB & Komerční banka & Česká spořitelna & Hypoteční banka \\
\hline \multirow{3}{*}{ NPM_post-NPM_pre } & Negative Ranks & $0 \mathrm{a}$ & $0 \mathrm{a}$ & $0 \mathrm{a}$ & $0 \mathrm{a}$ \\
\cline { 2 - 6 } & Positive Ranks & $3 \mathrm{~b}$ & $3 \mathrm{~b}$ & $3 \mathrm{~b}$ & $3 \mathrm{~b}$ \\
\cline { 2 - 6 } & Ties & $0 \mathrm{c}$ & $0 \mathrm{c}$ & $0 \mathrm{c}$ & $0 \mathrm{c}$ \\
\cline { 2 - 6 } & Total & $-1.604 \mathrm{~B}$ & $-1.604 \mathrm{~B}$ & $-1.604 \mathrm{~B}$ & $-1.604 \mathrm{~B}$ \\
\hline Z & & 0.109 & 0.109 & 0.109 & 0.109 \\
\hline Asymp. Sig. (2-tailed) & & & 3 & 0.09 \\
\hline
\end{tabular}

a. NPM_post $<$ NPM_pre

b. NPM_post $>$ NPM_pre

c. $N P M \_$post $=$NPM_pre

*significance level was set at 0.05

\section{Interpretation}

From the analysis we can see that the significance level for all the banks' NPM is more than 0.05 (Table 5), therefore the null hypothesis is accepted that there is no significant difference between the pre and the post-acquisition performance of the banks on the basis of NPM. But from the individual performance of the banks, we can find that for

all banks, the post-acquisition profit performance for all the three years has been better than the pre-acquisition period. So overall on the basis of the average pre and postacquisition net profit margin performance of the banks, the post-acquisition performance was better for all sample banks.

\section{Table 6.Changes in Debt-Equity (DE) Post-acquisition}

The table depicts the changes in the DE of the selected banks after the acquisition. For eg. Positive ranks- $3 b$ for ČSOB here shows that in all 3 years after the acquisition, DE was more as compared to the pre-acquisition years. 


\begin{tabular}{|l|l|r|r|r|r|}
\hline & Ranks & ČSOB & Komerční banka & Česká spořitelna & Hypoteční banka \\
\hline \multirow{5}{*}{ Debt-Equity_post-Debt-Equity_pre } & Negative Ranks & $0 \mathrm{a}$ & $3 \mathrm{a}$ & $3 \mathrm{a}$ & $2 \mathrm{a}$ \\
\cline { 2 - 6 } & Positive Ranks & $3 \mathrm{~b}$ & $0 \mathrm{~b}$ & $0 \mathrm{~b}$ & $1 \mathrm{~b}$ \\
\cline { 2 - 6 } & Ties & $0 \mathrm{c}$ & $0 \mathrm{c}$ & $0 \mathrm{c}$ & $0 \mathrm{c}$ \\
\cline { 2 - 6 } & Total & $-1.604 \mathrm{~B}$ & $-1.604 \mathrm{C}$ & $-1.604 \mathrm{C}$ & $-0.535 \mathrm{C}$ \\
\hline Z & & 0.109 & 0.109 & 0.109 & 0.593 \\
\hline Asymp. Sig. (2-tailed) & & & & &
\end{tabular}

a. Debt-Equity_post $<$ Debt-Equity_pre

b. Debt-Equity_post > Debt-Equity_pre

c. Debt-Equity_post $=$ Debt-Equity_pre

*significance level was set at 0.05

\section{Interpretation}

From the analysis we can see that the significance level for all the banks Debt Equity ratio is more than 0.05 (Table 6), therefore the null hypothesis is accepted that there is no significant difference between the pre and the post-acquisition performance of the banks on the basis of Debt Equity ratio.

Looking at the individual performance of the banks (Table 6), we can see that for Komerční banka a Česká spořitelna, the postacquisition performance on the basis of Debt Equity ratio for all the 3 years has been worse than the pre-acquisition period. Even for Hypoteční banka it was not good for 2 out of 3 years. Only in ČSOB, the Debt Equity ratio postacquisition performance was better than the pre period for all 3 years. So overall on the basis of the average pre and post-acquisition solvency performance of the banks on the basis of Debt Equity, the post-acquisition performance was worse for 3 out of the 4 sample banks.

\section{Table 7.Changes in earning per share (EPS) Post-acquisition}

The table depicts the changes in the EPS of the selected banks after the acquisition. For eg. Positive ranks- $3 b$ for EPS here shows that in all
3 years after the acquisition, EPS was more as compared to the pre-acquisition years.

\begin{tabular}{|l|l|r|r|r|r|}
\hline & Ranks & ČSOB & Komerční banka & Česká spořitelna & Hypoteční banka \\
\hline \multirow{5}{*}{ EPS_post-EPS_pre } & Negative Ranks & $0 \mathrm{a}$ & $0 \mathrm{a}$ & $0 \mathrm{a}$ & $0 \mathrm{a}$ \\
\cline { 2 - 6 } & Positive Ranks & $3 \mathrm{~b}$ & $3 \mathrm{~b}$ & $3 \mathrm{~b}$ & $3 \mathrm{~b}$ \\
\cline { 2 - 6 } & Ties & $0 \mathrm{c}$ & $0 \mathrm{c}$ & $0 \mathrm{c}$ & $0 \mathrm{c}$ \\
\cline { 2 - 6 } & Total & $-1.604 \mathrm{~B}$ & $-1.604 \mathrm{~B}$ & $-1.604 \mathrm{~B}$ & $-1.604 \mathrm{~B}$ \\
\hline Z & & 0.109 & 0.109 & 0.109 & 0.109 \\
\hline Asymp. Sig. (2-tailed) & & & 3 & 3 & 3 \\
\hline
\end{tabular}

a. EPS_post $<$ EPS_pre

b. EPS_post $>$ EPS_pre

c. EPS_post $=$ EPS_pre

*significance level was set at 0.05

\section{Interpretation}

By applying the Wilcoxon signed rank test, we can see that for all the 4 banks the significance level is more than 0.05 (Table 7), therefore the null hypothesis is accepted that there is no significant difference between the pre and the post-merger and acquisition performance on the basis of EPS of the banks.

But looking at individual banks, we can find that for all banks, the post-acquisition profit performance for all the three years has been better than the pre-acquisition period. So overall on the basis of the average pre and postacquisition earning per share performance of the banks, the post-acquisition performance was better for all sample banks.

\section{FINDINGS}

1. For $\check{C}$ SOB if we compare all the ratios, then we come to the see that only for the one parameter, which is the return of assets ratio, the post-acquisition performance has not improved for the bank. For rest all the parameters (Profitability, Solvency and Overall Efficiency), the performance has improved after the acquisition but not significantly.

2. For Komerční banka, comparing all the 
ratios, we can observe that for all the parameters except the solvency one, which is Debt-equity ratio, the post-acquisition performance has improved though not significantly.

3. For Česká spořitelna comparing all the ratios, we can see that for all the parameters except the solvency one, which is Debt-equity ratio, the post-acquisition performance has improved though not significant, the results are quite similar to Komerční banka.

4. For Hypoteční banka, the profitability parameter is giving a clear result as the Return on net worth and Earning per share is improving post-acquisition. However, solvency parameter is giving negative results for two years, and giving positive result, which is an improved post-acquisition performance for one year.

The overall impact though has not been significant enough to prove the fact that mergers and acquisitions lead to a change in the financial performance of the banks. Thus it is difficult to comment on the exact impact of acquisition on the profitability of the bank.

\section{LIMITATIONS}

There are certain limitations or weaknesses of this research study:

The limitation of this research study is the non-availability of financial data, information regarding financial data for some banks. The sample used for this research could be bigger.

Furthermore, since the time period for the comparison here was three years before and after the acquisition, the impact of the acquisitions could not be seen. Next, this study refers to the overall change in performance by comparing the post with the pre-acquisitions performance. How ever, some of this difference could be due to a continuation of firm-specific performance before the $M \& A$ or to economy wide and industry factors, or different types of variables influencing operational efficiency improvement in bank M\&A as stated by Healy et al. (1992). Also, the change of profit efficiency may be caused by changes in the pricing behavior of the acquired banks or decrease market power, etc., therefore, next researcher should investigate further those issues.

\section{CONCLUSION AND SCOPE FOR FURTHER RESEARCH}

As mentioned above, several benefits are sought from mergers and acquisitions, especially it is an improvement in bank performance. Even though numerous studies have been done in other countries, same cannot be said for the Czech Republic. There are no research exists on the effect of acquisitions on the performance of acquired banks, therefore this study attempts to look into and make a comparative analysis of the effects of acquisitions in the Czech banking system.

From the above analysis, we can state that acquisitions have increased profitability and solvency of banks in the Czech Republic, but not significantly. Also, we can see the overall impact of these acquisitions on the banks although not significant, it has been positive for the most of the parameters for all the banks. Hence, this study has accepted the null hypotheses which consider that significant difference between the financial performance of the banks before and after the acquisition and rejected the alternative hypothesis which considers that there is significance improvement. Thus, we can conclude that acquisitions are not leading to a significant change in the performance of banks. This study therefore not supports the value creation theories of mergers and acquisition. However, it would be mistaken to assume, on the basis of this study, that, acquisition activities are completely negative to banks.

Consequently, the paper endorse the idea, that the banks should put in place strategies that would improve their performance, financial efficiency, in order to gain more the benefits of post acquisitions.

There are also recommendations for next researches. Similar type of studies on impact of mergers and acquisitions on financial performance for companies in other sectors like telecommunication sector, IT sector etc. Furthermore, apart from the profitability and solvency, other performance ratios like liquidity, cash flow can be used to know the performance of banks undergone for $M \& A$ strategy. Next, the study can compare financial performance for cross-border acquisitions, either for acquiring or acquired companies. Last but not least, the different types of methodologies (DEA, t-test, univariate/multivariate analysis) could be applied. 


\section{ACKNOWLEDGMENTS}

This research has been supported by a grant IP 1000400.

\section{REFERENCES}

Altunbas, Y., Ibanez, D., M., (2008): Mergers and Acquisitions and Bank Performances in Europe. The role of strategic similarities, Journal of Economics and Business, Vol 60(3), p. 204-222.

Amel, D., Barnes, C., Panetta, F., Salleo, C., (2004): Consolidation and Efficiency in the Financial Sector: A Review of the International Evidence. Journal Banking \& Finance, Vol. 28(10), p. 2493-2519.

Badreldin, A., Kalhoefer, C., (2009). The Effect of Mergers and Acquisitions on Bank Performance in Egypt, Journal of Management Technology, p.1-15.

Bartošek, K., Felsbergová, D., Jaroš, P. (1998): Bankovnictví v České republice. Praha: Bankovní institute, 1998.

Beccali E., Frantz P., (2009): M\&A operations and performance in banking, Journal of Financial Services Research, Vol. 36(2), p. 203-226.

Beitel, P., Schiereck, D., Wahrenbur, M., (2004): Explaining the M\&A Success in European Bank, European Financial Management, Vol. 10(1), p. 109139.

Bonin, J., P., Hasan, I., Wachtel, P. (2005): Bank Performance, Efficiency and Ownership in Transition Countries, Journal Banking and Finance, Vol. 29 (1), p. 31-53.

Campa, J., M., Hernando, I. (2006): M\&As Performance in the European Financial Industry, Journal of Banking and Finance Vol. 30 (12), p. 3367-3392.

Clarke, G., R., G., Cull, R., Shirley, M. M. (2005): Bank Privatization in Developing Countries: A Summary of Lessons and Findings, Journal of Banking \& Finance 29, p. 1905-1930.

Cornett, M., M., McNutt J., J., Tehranian, H.,(2006): Performance changes around bank mergers: Revenue Enhancements Versus Cost Reductions, Journal of Money, Credit, and Banking, vol. 38(4), p. 1013-1050.

Correa, R. (2008): Cross-Border Bank Acquisitions: Is There a Performance Effect? Board of Governors of the Federal Reserve System, International Finance Discussion Papers no 922.

Česká bankovní asociace (2013): Zdraví a kapitálová vybavenost českého bankovního sektoru, stejně jako jeho odolnost proti krizím, zůstávají na vysoké úrovni, retrieved June 10, 2014, from http://www.investujeme.cz/zdravi-a-kapitalovavybavenost-ceskeho-bankovniho-sektoru-stejne-jakojeho-odolnost-proti-krizim-zustavaji-na-vysokeurovni/

Demirguc-Kunt, A., Detragiache, E., Merrouche, O., (2010): Bank capital: Lessons from the financial crisis, Journal of Money, Credit and Banking, Vol 45(6), p. 1147-1164.

Demirgüç-Kunt, A., Huizinga H., (2010): Are banks too big to fail or too big to save? International Evidence from Equity Prices and CDS Spreads, Journal of Banking \& Finance, Vol 37(3), p. 875-894.

DeLong, G., DeYoung, R. (2007): Learning by observing: information spillovers in the execution and valuation of commercial bank $M \& A s$. The journal of Finance, Vol. 62(1), p. 181-216.

DeYoung, R., (1997). Bank mergers, X-efficiency, and the market for corporate control, Managerial finance, Vol. 23(1), p. 32-47.

Ekkayokkaya, M., Holmes, P., Paudyal, K., (2009): The Euro and the Changing Face of European Banking: Evidence from Mergers and Acquisitions, European Financial Management, vol. 15, no. 2, p. 451-476

Focarelli, D., Panetta F., Salleo C., (2002): Why do banks merge?, Journal of Money Credit and Banking, Vol. 34(4), 1047-1066

Fraser, D., R., Zang, H., (2009): Mergers and Long-Term Corporate Performance: Evidence from CrossBorder Bank Acquisitions? Journal of Money, Credit, and Banking, Vol. 41(7), p. 1504-1513.

Healy, P., J., Palepu, K. G., Ruback R. S., (1992): Does corporate performance improve after mergers? Journal of Financial Economics 31, p. 135-175.

Kemal, M., U., (2011): Post-Merger Profitability: A Case of Royal Bank of Scotland (RBS). International Journal of Business and Social Science, Vol5(2), p. 157-162.

Healy, P., Palepu, K., Ruback, R., (1992): Does corporate performance improve after mergers? Journal of Financial Economics, Vol. 31(2), p. 135 - 175.

Knapp, M., Gart, A., Chaudhry, M. (2006): The Impact of Mean Reversion of Bank Profitability on PostMerger Performance in the Banking Industry, Journal of Banking and Finance, Vol. 30(12), p. 3503-3517.

MF: Finanční sektor v Česku je stabilizovaný. Banky vyšly z krize posíleny. (2011). Retrieved June 10, 2014, from http://byznys.ihned.cz/c1-52303080-mffinancni-sektor-v-cesku-je-stabilizovany-bankyvysly-z-krize-posileny

Mylonidis, N., and Kelnikola, I. (2005), Merging Activity in the Greek Banking System: A Financial Accounting Perspective, South-Eastern Europe Journal of Economics 1, p. 121-144.

Panetta, F., Schivardi F., Shum M., (2009): Do mergers improve information? Evidence from the loan market, Journal of Money Credit and Banking, Vol. 41(4), p. 673-709.

Rhoades, S., A., (1993): The Efficiency Effects of Horizontal Bank Mergers, Journal of Banking and Finance, Vol 17(3), p. 411-422.

Schiereck, D., Grüb, Sigl C., Unverhau, J., (2009). Investment Bank Reputation and Shareholder Wealth Effects in Mergers and Acquisitions. Research in International Business and Finance, Vol 23(3), p. 257-273.

Sinha, P., Gupta, S., (2011): Mergers and Acquisitions: A Pre-Post analysis for the Indian financial services sector, MPRA Paper No. 31253.

Singer,M. (2009): Dopad světové krize na finanční sektor $v \check{C} R$, retrieved June 10, 2014, from http://www.cnb.cz/cs/verejnost/pro_media/konferenc e_projevy/vystoupeni_projevy/download/singer_200 90720_czech_slovak_prof_com.pdf

Sufian, F., Habibullah, M., H., (2009). Do mergers and acquisitions leads to a higher technical and scale efficiency? A counter evidence from Malaysia. 
African Journal of Business Management, 3(8), p. 340-349.

Tůma, M. (2006): Bankovní sektor v době fúzí bank $i$ dohledu, retrieved June 10, 2014, from https://www.cnb.cz/cs/verejnost/pro_media/clanky_r ozhovory/media_2006/cl_06_060518b.html

Vencovský, F., Jindra, Z., Novotný, J., Půlpán, K., Dvořák, P., a kol. (2000): Dějiny bankovnictví v českých zemích, Praha: Bankovní institut, 2000.

Vennet R. V. (2002): Cross-border mergers in European Banking and bank efficiency, University of Gent Working Paper 152, 2002.
ABOUT THE AUTHOR

Long Hoang Pham, email: xphah01@vse.cz

Mr.Long Hoang Pham - is a Doctoral student in Accounting and Corporate Financial Management. He teaches at the Department of Corporate finance of University of Economics in Prague. His main research areas are mergers and acquisitions and corporate finance. He has presented papers at national and international scientific conferences and published multiple articles. 


\section{APPENDIX}

Table 8: Descriptive Statistics on ratios (CSOB)

\begin{tabular}{llllll}
\hline Descriptive Statistics CSOB & N & Mean & Std. Deviation & Minimum & Maximum \\
\hline RONW_pre & 3 & 10.6933 & 0.8286 & 9.7400 & 11.2400 \\
RONW_post & 3 & 15.8167 & 1.3162 & 14.3000 & 16.6600 \\
& & & & & \\
NPM_pre & 3 & 21.5067 & 2.4989 & 18.8700 & 23.8400 \\
NPM_post & 3 & 26.9300 & 1.4609 & 25.5000 & 28.4200 \\
& & & & & \\
EPS_pre & 3 & 0.0534 & 0.0030 & 0.0500 & 0.0553 \\
EPS_post & 3 & 0.1226 & 0.0063 & 0.1170 & 0.1290 \\
& & & & & \\
ROA_pre & 3 & 1.1467 & 0,0252 & 1.1200 & 1.1700 \\
ROA_post & 3 & 1.0700 & 0.0361 & 1.0400 & 1.1100 \\
& & & & & \\
DE_pre & 3 & 8.0600 & 0.8088 & 7.1700 & 8.7500 \\
DE_post & 3 & 13.3600 & 1.1521 & 12.1700 & 14.4700 \\
\hline
\end{tabular}

Source: SPSS OUTPUT

Table 9: Descriptive Statistics on ratios (Komercni banka)

\begin{tabular}{llllll}
\hline Descriptive Statistics KB & N & Mean & Std. Deviation & Minimum & Maximum \\
\hline RONW_pre & 3 & 28.5500 & 24.1259 & -46.3900 & -1.1000 \\
RONW_post & 3 & 24.4200 & 4.8701 & 20.7300 & 29.9400 \\
& & & & & \\
NPM_pre & 3 & -27.4900 & 23.0593 & -41.8200 & -0.8900 \\
NPM_post & 3 & 36.8967 & 1.1812 & 35.5600 & 37.8000 \\
& & & & & \\
EPS_pre & 3 & -0.0341 & 0.0289 & -0.0525 & -0.0008 \\
EPS_post & 3 & 0.0233 & 0.0005 & 0.0228 & 0.0237 \\
ROA_pre & 3 & -1.5100 & 1.2646 & -2.2600 & -0.0500 \\
ROA_post & 3 & 1.9733 & 0.0757 & 1.9200 & 2.0600 \\
DE_pre & & & & & \\
DE_post & 3 & 19.1533 & 0.8010 & 18.3300 & 19.9300 \\
\hline
\end{tabular}

Source: SPSS OUTPUT

Table 10: Descriptive Statistics on ratios (Ceska sporitel na)

\begin{tabular}{llllll}
\hline Descriptive Statistics CS & N & Mean & Std. Deviation & Minimum & Maximum \\
\hline RONW_pre & 3 & -6.6733 & 18.6970 & -27.8300 & 7.6300 \\
RONW_post & 3 & 23.0467 & 0.6600 & 22.3900 & 23.7100
\end{tabular}




\begin{tabular}{llllll} 
NPM_pre & 3 & -8.4567 & 19.4360 & -30.7100 & 5.1900 \\
NPM_post & 3 & 18.4567 & 0.8000 & 17.6600 & 19.2600 \\
EPS_pre & 3 & -0.0010 & 0.0028 & -0.0041 & 0.0012 \\
EPS_post & 3 & 0.0055 & 0.0005 & 0.0050 & 0.0060 \\
& & & & & \\
ROA_pre & 3 & -0.3933 & 1.0451 & -1.5800 & 0.3900 \\
ROA_post & 3 & 1.4433 & 0.0322 & 1.4200 & 1.4800 \\
& & & & & \\
DE_pre & 3 & 17.6600 & 1.8749 & 15.5400 & 19.1000 \\
DE_post & 3 & 14.7633 & 0.4970 & 14.2000 & 15.1400 \\
\hline
\end{tabular}

Source: SPSS OUTPUT

Table 11: Descriptive Statistics on ratios (Hypotecni banka)

\begin{tabular}{llllll}
\hline Descriptive Statistics HB & N & Mean & Std. Deviation & Minimum & Maximum \\
\hline NPM_pre & 3 & 24.6900 & 33.12661 & -13.5600 & 44.0900 \\
NPM_post & 3 & 52.5300 & 6.0294 & 45.5700 & 56.1600 \\
RONW_pre & 3 & 4.6267 & 5.9834 & -2.2800 & 8.2400 \\
RONW_post & 3 & 10.3733 & 1.3628 & 8.8800 & 11.5500 \\
& & & & & \\
EPS_pre & 3 & 0.0058 & 0.0083 & -0.0037 & 0.0116 \\
EPS_post & 3 & 0.0238 & 0.0049 & 0.0182 & 0.0275 \\
& & & & & \\
ROA_pre & 3 & 0.6000 & 0.7571 & -0.2700 & 1.1100 \\
ROA_post & 3 & 1.3733 & 0.2136 & 1.1300 & 1.5300 \\
DE_pre & 3 & 7.1500 & 1.2998 & 5.9200 & 8.5100 \\
DE_post & 3 & 6.4533 & 0.2640 & 6.2200 & 6.7400 \\
\hline
\end{tabular}

Source: SPSS OUTPUT 
